\title{
ANALISIS KINERJA KEUANGAN PADA PT. BANK PERKREDITAN RAKYAT (BPR) BATANG KAPAS PESISIR SELATAN
}

\author{
Dina Septi Rahmayeli, Doni Marlius \\ Akademi Keuangan dan Perbankan Padang \\ donimarlius@akbpstie.ac.id
}

\begin{abstract}
The purpose of this study was to determine the financial condition based on liquidity ratio, colvency ratio, and profitability ratios in the PT. Bank Perkreditan Rakyat (BPR) Batang Kapas Pesisir Selatan in the years 2013 - 2015. Field rasearch method by approaching directly to the company that became the object of study. Book study library to research conducted by several scientific books and papers relating to discussion conducted. The total assets in 2013 was Rp. 20.405.837.239 and increased in 2014 to Rp. 21.845.491.637, and in 2015 also increased to at Rp. 24.383.506.204. In 2013 the number of sales of Rp. 3.527.453.681 the company makes a profit of Rp. 386.631.825. In 2014 sales increasednto as much Rp. 3.820.802.620 with profit Rp. 440.536 .679 and also increased from the previous year. In 2015 the company sales increased much $R p$. 4.127.157.198, and makes a profit of Rp. 504.013.708.
\end{abstract}

Keywoard: Analysis, Performance, Finance

\section{PENDAHULUAN}

Latar Belakang

Perkembangan dunia

perbankan di Indonesia saat ini semakin kompetitif yang mana menuntut setiap perbankan untuk dapat mengolah dan melaksanakan manajemen perbankan menjadi lebih profesional.

Bank merupakan badan usaha yang tugas utamanya sebagai lembaga perantara keuangan (financial intermediaries), yang menyalurkan dana dari pihak yang berkelebihan dana kepada pihak yang membutuhkan dana atau kekurangan dana pada waktu yang ditentukan.
Kinerja keuangan bank dapat diukur dengan rasio likuiditas, rasio solvabilitas, dan rasio profitabilitas. Laporan keuangan merupakan suatu proses untuk membantu memecahkan dan sekaligus menjawab masalahmasalah yang timbul dalam suatu organisasi perusahaan maupun organisasi yang tidak bertujuan untuk memperoleh laba (Drs. Amin Widjaja 2000:22).

Kinerja keuangan PT. Bank Perkreditan Rakyat Batang Kapas Pesisir Selatan untuk tahun 2013 sampai 2015 dapat diketahui melalui 
laporan keuangan yang berupa laporan neraca dan laporan rugi/laba pada tahun 2013 sampai 2015. Laporan keuangan tersebut selanjutnya dianalisa dengan menggunakan analisis rasio keuangan yaitu meliputi : rasio likuiditas, rasio solvabilitas, dan rasio profitabilitas.
Berikut ini laporan laba

rugi PT. BPR Batang Kapas untuk periode 2013 sampai dengan periode 2015 .

\section{Tabel 1}

Laporan Laba Rugi PT. BPR Batang Kapas

Tahun 2013-2015 (Rupiah)

\begin{tabular}{|l|c|c|c|}
\hline \multicolumn{1}{|c|}{ Keterangan } & $\mathbf{2 0 1 3}$ & $\mathbf{2 0 1 4}$ & $\mathbf{2 0 1 5}$ \\
\hline Penjualan & 3.527 .453 .681 & 3.820 .802 .620 & 4.127 .157 .198 \\
\hline Laba Bersih & 386.631 .825 & 440.536 .679 & 504.013 .708 \\
\hline
\end{tabular}

Sumber: Laporan Laba Rugi PT. BPR Batang Kapas

Pada Tahun 2013 dengan

jumlah penjualan sebesar Rp. 3.527.453.681

perusahaan

memperoleh laba sebesar Rp. 386.631.825. Pada Tahun 2014 penjualan meningkat dari tahun sebelumnya, dimana jumlah penjualan adalah sebesar Rp. 3.820.802.620 sehingga laba yang diperoleh juga mengalami peningkatan dimana jumlah laba yang diperoleh pada Tahun 2014 adalah sebesar Rp. 440.536.679. Pada Tahun 2015 penjualan juga mengalami peningkatan lagi dari tahun sebelumnya adalah sebesar Rp. 4.127.157.198, dan laba yang dihasilkan juga mengalami penambahan dari tahun sebelumnya menjadi sebesar Rp. 504.013.708.

\section{Rumusan Masalah}

Berdasarkan latar belakang masalah diatas maka rumusan masalah dalam penelitian ini adalah bagaimana kondisi keuangan PT.
Bank Perkreditan Rakyat Batang Kapas Pesisir Selatan serta perkembangan posisi keuangan PT. Bank Perkreditan Rakyat Batang Kapas Pesisir Selatan tiap tahunnya jika dilakukan perbandingan?

\section{Tinjauan Pustaka \\ Bank Perkreditan Rakyat (BPR)}

(BPR) yaitu bank yang melaksanakan kegiatan usaha secara konvensional atau berdasarkan prinsip syariah, tetapi tidak memberikan jasa dalam lalu lintas pembayaran.

\section{Lembaga Keuangan}

Menurut UU RI pasal 1 ayat 2 No. 10 tahun 1998 tentang perbankan mendefinisikan bahwa "Bank adalah badan usaha yang menghimpun dana dari masyarakat dalam bentuk simpanan dan menyalurkannya kepada masyarakat dalam bentuk kredit dan atau bentukbentuk lainnya dalam rangka 
meningkatkan taraf hidup rakyat banyak".

\section{Kinerja Keuangan}

Kinerja keuangan perusahaan menurut Munawir: 2000, merupakan suatu gambaran tentang kondisi keuangan suatu perusahaan yang dianalisis dengan alat-alat analisis keuangan, sehingga dapat diketahui mengenai baik buruknya keadaan keuangan suatu perusahaan yang mencerminkan prestasi kerja dalam periode tertentu.

\section{Laporan Keuangan}

1) Pengertian Laporan Keuangan

Menurut Harahap (2004:7)

mengemukakan bahwa: "Laporan keuangan adalah pokok atau hasil akhir dari suatu proses akuntansi yang menjadi bahan informasi bagi para pemakainya sebagai salah satu bahan dalam proses pengambilan keputusan dan juga dapat menggambarkan indikator kesuksesan suatu perusahaan mencapai tujuannya".

2) Pihak-pihak yang Memperoleh Laporan Keuangan

Menurut Drs. Amin Widjaja (2000:23) pihak-pihak yang membutuhkan laporan keuangan adalah sebagai berikut:
a. Pimpinan Perusahaan
b. Kreditur
c. Penanaman Modal (Investor)
d. Pemerintah
e. Karyawan
f. Akuntan Publik

3) Jenis Laporan Keuangan

Menurut Harahap (2010:106) jenis Laporan keuangan terdiri dari beberapa komponen-komponen sebagai berikut:

a. Daftar neraca yang menggambarkan posisi keuangan perusahaan pada suatu tanggal tertentu.

b. Perhitungan laba/rugi yang menggambarkan jumlah hasil, biaya dan laba/rugi perusahaan pada suatu periode tertentu.

c. Laporan sumber dan penggunaan dana

d. Laporan arus kas

\section{Rasio Keuangan}

Kinerja keuangan bank dapat diukur dengan menggunakan rasio keuangan, antara lain: rasio likuiditas, rasio solvabilitas, dan rasio profitabilitas.

\section{Rasio Likuiditas}

Yaitu menggambarkan kemampuan perusahaan untuk menyelesaikan kewajiban jangka pendeknya.

\section{Rasio Solvabilitas}

Yaitu menggambarkan kemampuan perusahaan dalam membayar kewajiban jangka panjang maupun kewajiban-kewajibannya yang apabila perusahaan dilikuidasi.

\section{Rasio Profitabilitas}

\begin{tabular}{lrr}
\multicolumn{1}{c}{ Adalah } & rasio yang \\
menunjukkan & kemampuan \\
perusahaan untuk & memperoleh \\
keuntungan dari pengguna modalnya.
\end{tabular}


Tabel 2

Penilaian Ratio Rata-Rata Industri Menurut BI

\begin{tabular}{|l|c|c|c|}
\hline \multirow{2}{*}{ Rasio Keuangan } & \multicolumn{2}{|c|}{ Rata-Rata Industri } & \multirow{2}{*}{ Kategori } \\
\cline { 2 - 3 } 1. Rasio Likuiditas & Angka & Persentase & \\
Current Ratio & & & Baik \\
Cash Ratio & $>2$ & $200 \%$ & Baik \\
\hline 2. Rasio Solvabilitas & $>0,3$ & $30 \%$ & \\
Debt Ratio & $>0,35$ & $35 \%$ & Baik \\
Debt Equity Ratio & $>0,9$ & $90 \%$ & Baik \\
\hline 3. Rasio Profitabilitas & & & \\
Gross Profit Margin & $>0,3 \%$ & $30 \%$ & Baik \\
Net Profit Margin & $>0,1$ & $10 \%$ & Baik \\
Return On Investment & $>0,3$ & $30 \%$ & Baik \\
Return On Equity & $>0,05$ & $5 \%$ & Baik \\
Return On Asset & $>0,005$ & $0,5 \%$ & Baik \\
\hline
\end{tabular}

Sumber: BEI

\section{Metode Penelitan}

\section{Metode Pengumpulan data}

a. Penelitian Lapangan (Field Research)

Yaitu suatu metode penelitian dengan cara mendatangi langsung ke perusahaan yang menjadi objek kajian.

b. Studi Pustaka (Library Research)

Yaitu penelitian yang dilakukan ke perpustakaan dengan beberapa bukubuku ilmiah dan tulisan-tulisan yang

\section{Hasil dan Pembahasan}

\section{Analisis Rasio Likuiditas \\ a. Current Ratio}

Rasio ini menunjukkan nilai kekayaan lancar (segera dapat dijadikan uang) yang dimiliki oleh perusahaan.

Rumus: $\frac{\text { Aktiva Lancar }}{\text { Hutang Lancar }} \times 100 \%$

b. Cash Ratio

Rasio ini adalah rasio yang paling konservatif untuk mengukur kemampuan perusahaan untuk memenuhi kewajiban lancarnya berhubungan dengan pembahasan yang dilakukan.

\section{Medtode Analisa Data}

Dalam menganalisa data, penulis menggunakan analisa data kuantitatif sebagai metode penelitian yang menjelaskan secara deskriptif mengenai analisa rasio terhadap laporan keuangan PT. Bank Perkreditan Rakyat Batang Kapas Pesisir Selatan untuk periode 2013 sampai 2015.

dengan menggunakan aktiva-aktiva kas dan atau setara kas.

Rumus: $\frac{\text { Kas }+ \text { Bank }+ \text { Surat Berharga }}{\text { Hutang Lancar }} \times$ $100 \%$

\section{Analisi Rasio Solvabilitas}

a. Debt Ratio (Rasio Hutang)

Merupakan rasio yang mengukur berapa persen aset perusahaan yang dibelanjai dengan hutang.

Rumus: $\frac{\text { Total Hutang }}{\text { Total Aktiva }} \times 100 \%$

\section{b. Total Debt to Equity Ratio}

Merupakan perbandingan dari total hutang yang dimiliki perusahaan 
dengan modal sendiri (ekuitas). Artinya bagian dari setiap rupiah modal sendiri yang dijadikan jaminan untuk keseluruhan hutang perusahaan.

Rumus: $\frac{\text { Total Hutang }}{\text { Modal Sendiri }} \times 100 \%$

3. Analisis Rasio Profitabilitas

a. Rasio Margin Laba Kotor (Gross Profit Margin)

Rasio ini digunakan untuk menggambarkan kemampuan perusahaan dalam mendapatkan laba atau deviden.

Rumus: $\frac{\text { Laba Kotor }}{\text { Penjualan }} \times 100 \%$

b. Rasio Margin Laba Bersih (Gross Net Profit)

Rasio ini digunakan untuk menghitung berapa persen keuntungan bersih yang diperoleh ole perusahaan selama periode tertentu (tahun buku) dari setiap rupiah penjualan.

Rumus: $\quad \frac{\text { Laba bersih setelah pajak }}{\text { Penjualan Bersih }} \times$ $100 \%$

\section{Pembahasan}

\section{a. Rasio Likuiditas}

c. Return On Investment (Rasio Pengembalian Atas Aktiva)

Rasio ini mengukur pengembalian atas total aktiva setelah bunga dan pajak.

Rumus: $\quad \frac{\text { Laba Bersih Setelah Pajak }}{\text { Total Aktiva }} \times$ $100 \%$

d. Return On Equity (ROE)

Digunakan untuk mengukur banyaknya keuntungan yang menjadi hak pemilik modal sendiri.

Rumus: $\quad \frac{\text { Laba bersih setelah pajak }}{\text { Modal sendiri }} \times$ $100 \%$

e. Return On Assets (ROA)

untuk mengukur kemampuan perusahaan dalam memperoleh laba perusahaan dengan aktiva yang digunakan untuk memperoleh laba tersebut. ROA dihitung dengan membagi laba usaha (EBIT) dengan total aktiva.

Rumus: $\frac{\text { Laba usaha atau (EBIT) }}{\text { Total aktiva }} \times 100 \%$

Tabel 3

Perbandingan Rasio Likuiditas

PT. BPR Batang Kapas Tahun 2013 - 2015

\begin{tabular}{|l|r|r|r|c|}
\hline Rasio & \multicolumn{1}{|c|}{$\mathbf{2 0 1 3}$} & \multicolumn{1}{c|}{$\mathbf{2 0 1 4}$} & \multicolumn{1}{c|}{$\mathbf{1 0 1 5}$} & Rata Industri \\
\hline Current Ratio & $127,45 \%$ & $129,32 \%$ & $117,93 \%$ & $200 \%$ \\
\hline Cash Ratio & $12,93 \%$ & $21,22 \%$ & $20,56 \%$ & $30 \%$ \\
\hline
\end{tabular}

Sumber : Rasio Likuiditas PT. BPR Batang Kapas Tahun 2013-2015

b. Rasio Solvabilitas

Tabel 4

Perbandingan Rasio Solvabilitas

PT. BPR Batang Kapas Tahun 2013 - 2015

\begin{tabular}{|l|c|c|c|r|}
\hline Rasio & \multicolumn{1}{|c|}{$\mathbf{2 0 1 3}$} & $\mathbf{2 0 1 4}$ & $\mathbf{2 0 1 5}$ & Rata Industri \\
\hline Debt Ratio & $85,60 \%$ & $86,21 \%$ & $85,34 \%$ & $35 \%$ \\
\hline Debt Equity Ratio & $831,27 \%$ & $896,30 \%$ & $799,89 \%$ & $90 \%$ \\
\hline
\end{tabular}

Sumber:Rasio Solvabilitas PT. BPR Batang Kapas Tahun 2013 - 2015 


\section{c. Rasio Profitabilitas}

Tabel 5

Perbandingan Rasio Profitabilitas PT. BPR Batang Kapas

Tahun 2013 - 2015

\begin{tabular}{|l|r|r|r|r|}
\hline Rasio & \multicolumn{1}{|c|}{$\mathbf{2 0 1 3}$} & \multicolumn{1}{|c|}{$\mathbf{2 0 1 4}$} & \multicolumn{1}{|c|}{$\mathbf{2 0 1 5}$} & \multicolumn{1}{c|}{$\begin{array}{c}\text { Rata } \\
\text { Industri }\end{array}$} \\
\hline Gross Profit Margin & $12,51 \%$ & $12,52 \%$ & $13,21 \%$ & $30 \%$ \\
\hline Net Profit Margin & $10,96 \%$ & $11,52 \%$ & $12,21 \%$ & $10 \%$ \\
\hline Return On Investment & $1,89 \%$ & $2,01 \%$ & $2,06 \%$ & $30 \%$ \\
\hline Return On Equity & $18,39 \%$ & $20,96 \%$ & $19,37 \%$ & $5 \%$ \\
\hline Return On Asset & $2,16 \%$ & $2,19 \%$ & $2,23 \%$ & $0,5 \%$ \\
\hline
\end{tabular}

Sumber: Rasio Profitabilitas PT. BPR Batang Kapas tahun 2013 - 2015

\section{Kesimpulan dan Saran}

\section{Kesimpulan}

Berdasarkan analisa laporan keuangan dengan menggunakan rasio likuiditas, solvabilitas, dan profitabilitas dalam menilai kinerja keuangan pada PT. BPR Batang Kapas dari Tahun 2013 sampai dengan 2015, dapat ditarik kesimpulan yaitu tingkat likuiditas pada Tahun 2013 sampai dengan 2015 terlihat kurang efisien atau kurang baik. Tingkat solvabilitas perusahaan pada Tahun 2013 sampai dengan 2015 terlihat sangat baik. Walaupun disana terlihat bahwa setiap tahun terjadi penurunan dan peningkatan, baik dari segi debt ratio maupun debt equity ratio. Dari tingkat rasio profitabilitas

\section{Daftar Pustaka}

Drs.Amin Widjaja Tunggal Ak.MBA, 2000, Dasar-Dasar Analisis Laporan Keuangan, PT Rineka Cipta, Jakarta.

Ketetapan UU RI Pasal 1 ayat 2 No. 10 Tahun 1998 Tentang Perbankan, Jakarta. perusahaan dari Tahun 2013 sampai dengan 2015 secara keseluruhan juga menunjukkan rasio yang berfluktuasi atau tidak menentu dari tahun ketahun.

\section{Saran}

Berdasarkan masalah yang dihadapi dalam perhitungan kinerja perusahaan, maka saran yang diberikan yaitu untuk rasio profitabilitas pada PT. BPR Batang Kapas harus lebih mengembangkan produk dan kualitas pelayanan jasa nya, agar untuk ratio profitabilitasnya meningkat dari tahun ketahun, dan bisa menjadi lembaga perbankan yang dipercaya oleh masyarakat setempat, serta mampu berkontribusi di dunia perbankan.

Munawir S, 2000, Analisa Laporan Keuangan, Yogyakarta: Liberty.

Munawir S, 2004, Analisa Laporan Keuangan, Yogyakarta: Liberty.

Harahap Sofyan Syafri, 2004, Analisi Kritis Atas Laporan Keuangan, Jakarta: Rajawali. 
Harahap Sofyan Syafri, 2010, Analisi Kritis Atas Laporan Keuangan, Jakarta: Rajawali.

Kasmir, 2008, Analisis Laporan Keuangan, Jakarta: Rajawali Pers.
Sutojo Siswanto F.Kleinsteuber, 2004, Manajemen Keuangan Bagi Eksekutif NonKeuangan, Damar Mulia Pustaka, Jakarta. 